\title{
ADMISSION IN STATE COURTS OF EVIDENCE ILLEGALLY SEIZED BY FEDERAL OFFICERS
}

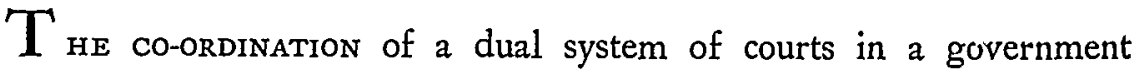
organized on a federal basis poses two closely related problems. The more basic of these concerns the constitutional allocation of judicial power between the state and federal courts. ${ }^{1}$ And, secondarily, there arises the question as to the extent to which principles of comity should restrain the federal courts from exercising a constitutionally recognized power in a manner which might be offensive to state autonomy. ${ }^{2}$

This latter problem most recently confronted the Supreme Court in Rea v. United States. ${ }^{3}$ There, a federal narcotics agent had seized evidence which incriminated Rea under the Internal Revenue Code, ${ }^{4}$ but the subsequent federal prosecution was dismissed after a determination that the evidence had been seized in violation of the Federal Rules of Criminal Procedure. ${ }^{5}$ Thereafter, the federal agent procured an indictment in a state court ${ }^{6}$ and was preparing to introduce the illegally obtained evidence in the state prosecution when Rea sought injunctive relief from the federal courts. ${ }^{7}$ In a 5-4 decision, the Supreme Court

\footnotetext{
${ }^{x}$ This subject, of course, has innumerable ramifications. See, generally, 3 SELECTED Essays on Constitutional Law, cc. 13, 14 (1938); Hart, The Relations Befween State and Federal Law, 54 Colum. L. Rev. 489 (1954); Corwin, The Passing of Dual Federalism, 36 VA. L. REv. I (1950); Warren, Federal and State Court lnterference, 43 HaRv. L. Rev. 345 (1930).

${ }^{3}$ This question has received an excellent treatment in Taylor \& Willis, The Power of Federal Courts to Enjoin Proceedings in State Courts, 42 YAlE L.J. 1169 (1933). See also, Comments, 28 Tex. L. Rev. 4 10 (1950), 19 U. CHI. L. Rev. 361 (1952); Notes, 40 Calif. L. Rev. 300 (1952), 48 Colum. L. Rev. 575 (1948), 5 Duke B.J. 102 (1956). Cases dealing with the point include Toucey v. New York Life Ins. Co., 314 U.S. 118 (19+1); Ponzi v. Fessenden, 258 U.S. 254 (1922); In re Sawyer, 124 U.S. 200 (1888); Gilchrist v. Interborough Co., 279 U.S. 159 (1929).

${ }^{3}{ }_{76}$ Sup. Ct. 292 (1956).

50 STAT. 555 (1937), 26 U.S.C. § 2598 (a) (1952).

- The federal agent had acted under a warrant which failed to meet the requisites of Rule $41(\mathrm{c})$. Dismissal of the indictment followed a granting of petitioner's motion under Rule 41 (e) to suppress the illegally procured evidence. For a discussion of certain procedural problems arising under Rule 41(e), see Note, 5 DukE B.J. 110 $(1956)$.

${ }^{\circ}$ The indictment was procured under the New Mexico Narcotic Drug Act. N.M. Stat. ANN. c. 54, art. 7 (1953).

${ }^{7}$ In the district court, Rea sought ( 1 ) to enjoin the federal agent from testifying in the state court action concerning the evidence which had been illegally seized, and
} 
directed the issuance of the injunction against the federal agent. 8

The majority opinion of Justice Douglas does not expressly rest the decision on the general equity powers of the federal courts. Instead, the injunction seems to issue solely out of the Court's 'supervisory powers over federal law enforcement agencies." If, in fact, the Court intended to assert such "supervisory powers" as a separate and distinct basis for the federal injunctive power, then the decision involves an unprecedented expansion of judicial authority. As the dissent expresses it: ${ }^{\mathbf{1 0}}$

[T] his is the first time that it has been suggested that the federal courts share with the executive branch of the Government responsibility for supervising law enforcement activities as such.

This suggestion that the federal courts have a supervisory power independent of their ordinary equitable powers is likely to give rise to confusion as to the scope of this novel prerogative and as to the manner in which it may be exercised. ${ }^{11}$

There is however, a second and somewhat less theoretical objection to the reasoning of the majority. It is indisputable that the federal courts, acting as courts of equity, are constitutionally invested with the injunctive power here asserted; ${ }^{12}$ but there still remains the question as to whether they should abstain from its exercise in deference to

(2) to order the agent to reacquire the evidence, if it had been removed from the custody of the United States, and to destroy it or transfer it to other federal agents. The district court denied the injunction and the court of appeals affirmed. Rea v. United States, 218 F.2d 237 (1 oth Cir. 1954).

${ }^{8}$ Chief Justice Warren and Justices Black, Frankfurter, and Clark joined in the majority opinion of Justice Douglas. Justice Harlan was joined in his dissenting opinion by Justices Reed, Burton, and Minton.

- "In this posture we have then a case that raises not a constitutional question but one concerning our supervisory powers over federal law enforcement agencies." 76 Sup. Ct. at 294, citing McNabb v. United States, 318 U.S. 332 (1943). Justice Harlan, in his dissent, questioned the existence of any precedent to support this basis of the majority opinion. The $M c N a b b$ decision holds that the "supervision of the adininistration of criminal justice in the federal courts" is a power vested in the Supreme Court. 318 U.S. at 340. [Emphasis added.] See also a later application of the $M c N a b b$ rule in Gallegos v. Nebraska, 342 U.S. 55,64 (1951). Batt cf. Upshaw v. United States, 335 U.S. 410, 412 (1948).

${ }^{10} 76$ Sup. Ct. at $294-95$.

${ }^{11}$ See Beisel, Control over Illegal Enforcement of the Criminal Law: Role of the Supreme Court, 34 B.U.L. REv. 4 I3 (1954).

${ }^{12}$ See Taylor \& Willis, supra note 2. 
the state judicial process. ${ }^{13}$ By purporting to assert its supervisory powers over federal agents, as distinct from its equitable powers of injunction, the Court obviated that balancing of intersts which traditionally accompanies the issuance of an injunction ${ }^{14}$-a failure particularly unfortunate in the sensitive area of federal-state relations.

As in all cases in this area, there should be a weighing of the federal interest to be furthered against the respect owed to state autonomy. This latter element should be measured by the amount of interference with the state authority which the issuance of the injunction would entail. In the Rea decision, there is at least implied a distinction between a direct and an indirect interference. ${ }^{15}$ An instance of direct interference would be the issuance of an injunction against the state officials; and the Supreme Court, in Stefanelli v. Minard, ${ }^{10}$ refused to issue such an injunction prohibiting the use of evidence illegally obtained by state officials. On the other hand, it might be argued that the injunction sought in the Rea case would affect the state prosecution only indirectly, since it runs against the federal agent.. ${ }^{17}$

${ }^{13}$ The doctrine of "equitable abstention" has recently been discussed in Note, 5 DukE B.J. 102 (1956). The Court has always felt compelled to move cautiously when faced with a problem involving federal-state relations. "To justify such interference there must be exceptional circumstances and a clear showing that an injunction is necessary in order to afford adequate protection of constitutional rights." Spielman Motor Co. v. Dodge, 295 U.S. 89, 95 (1935). See also Screws v. United States, 325 U.S. 9I, 108 (1945); Beal v. Missouri Pacific R.R. Co., 312 U.S. 45 (194I). The Court has often held that equity will not restrain criminal proceedings. In re Sawyer, 124 U.S. 200, 21 I (1888); Davis \& Farnum Mfg. Co. v. Los Angeles, 189 U.S. 207 (1903); Hygrade Provision Co. v. Sherman, 266 U.S. 497, 500 (1925).

A converse situation recently arose in the case of Weiner v. Kelly, 82 So.2d 155 Fla. (1955), wherein an action was brought to enjoin state officers from introducing illegally obtained evidence in a federal prosecution. The injunction was denied on the ground that there had been no showing of unusual circumstances or irreparable loss.

1s The dissenting opinion of Justice Harlan begins with the observation that the majority decision is announced "without discussion of the competing state and federal interests involved."

15 "The District Court is not asked to enjoin state officials nor in any way to interfere with state agencies in enforcement of state law. Cf. Boske v. Comingore, 177 U.S. 459. . . The only relief asked is against a federal agent. . ." $76 \mathrm{Sup}$. Ct. at 294 . Thus the Court implicitly recognizes that its decision indirectly thwarts a state prosecution. Cf. Stefanelli v. Minard, 342 U.S. I17, 120 (195I): "We hold that the federal courts should refuse to interfere in State criminal proceedings to suppress the use of evidence even when claimed to have been secured by unlawful search and seizure."

${ }^{16} 342$ U.S. 117 (1951). See Falknor, Evidence, I951 ANNUAL Survey Am. L. 835,843 ; Note 38 VA. L. Rev. 514 (1952).

${ }_{17}$ This is the reasoning of the majority in the principal case. See note 15 supra. 
Categorical distinctions, however, seldom reflect a careful consideration of the competing interests involved; and, as the dissent demonstrates, this particular distinction would be difficult to maintain under a different set of facts. ${ }^{18}$ Instead, it would seem better to argue, in terms of degree rather than kind, that the affront to the states is somewhat less when the injunction is directed against a federal official. Perhaps this is true in an abstract sense; but, realistically, the effect of the injunction is the same in both cases: to deny to the state courts the evidence offered by the person sought to be enjoined. Consequently, if the degree of practical interference is, in fact, to be the measure of the deference owed to the states, there should be no distinction in this respect between the Rea case and the Stefanelli case. Instead, the determinative question must be whether the federal interest sought to be served in the one is greater than that in the other.

In identifying the federal interest involved in the Rea case, it is necessary first to distinguish between that interest and the interest of the defendant, Rea, who is concerned only with protecting himself against the illegally obtained evidence. Such evidence would clearly be inadmissible in the federal courts under the federal exclusionary rule propounded in Weeks v. United States. ${ }^{19}$ In the later case of Wolf v. Colorado, ${ }^{20}$ however, the Supreme Court held that the due process clause of the fourteenth amendment did not extend this exclusionary rule to the states. ${ }^{21}$ This decision necessarily means that there can be no federal interest in protecting a defendant against the use by a state

\footnotetext{
${ }^{18}$ In arguing that the practical effect of the injunction made it tantamount to a "direct" restraint upon the state proceedings, the dissent questioned how the majority would rule if the state had issued a subpoena to compel the presence of the federal agent. It was asserted that to prevent the officer's appearance in that instance would directly interfere with the state criminal proceeding. 76 Sup. Ct. at 295 .

${ }^{10} 232$ U.S. 383 (1914). For a discussion of the federal exclusionary rule and an

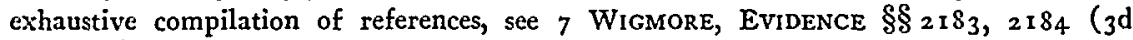
ed. 1940).

${ }^{20} 338$ U.S. 25 (1949). See Allen, The Wolf Case: Search and Seizure, Federalism, and the Civil Liberties, 45 ILL. L. Rev. I (1950); Biesel, Control over Illegal Enforcement of Criminal Law: Role of the Supreme Court, 34 B.U.L. REv. 41 3, 435-443 (1954); Perlman, Due Process and the Admissibility of Evidence, 64 HARv. L. REv. 1304 (1951). Notes, 50 Colum. L. REv. 364 (1950), 35 CoRNell L.Q. 625 (1950).

${ }_{21}^{21}$ In the Wolf case the Court for the first time declared that the due process clause of the fourteenth amendment made the fourth amendment's prohibition of "unreasonable searches and seizures" enforceable against the states. 338 U.S. at $27-28$. The Court was careful to point out, however, that the exclusionary rule of the Weeks case was merely a rule of evidence which could be negated by congressional enactment, not a requirement imposed by the fourth amendment. 328 U.S. at 39-40.
} 
court of evidence illegally obtained. ${ }^{22}$ Therefore, the question of whether any protection should, in all fairness, be extended to the defendant is a legally irrelevant consideration in determining whether the injunction should issue. As a result, in the Stefanelli case, where the injunction was sought against state officials, the Court implicitly recognized that there was no "important countervailing federal interest" involved. ${ }^{23}$ If such an interest is to be found in the Rea case, therefore, it must arise out of the fact that an injunction is sought against a federal agent who has violated a federal rule, without regard to the consequences of such a violation in subsequent state court proceedings.

It is in this context that the asserted supervisory power of the federal courts over federal agents acquires its proper significance. ${ }^{24}$ It is clearly the policy of the federal courts to encourage obedience to the federal rules; and if this policy would be served by the issuance of an injunction here, then that fact may be counterbalanced against the concomitant interference with state autonomy. But there must be a careful disinction drawn between justifying the injunction on the ground that it will deter federal officers from illegally seizing evidence in the future and justifying it on the ground that the federal courts should not countenance a violation of the federal rules even though the violation is complete. The latter justification cannot be advanced consistently with the rationale of Wolf $v$. Colorado, because the injunction effectively operates not as a sanction upon the federal agent who has already violated the rules, but rather as a restraint upon the state

${ }^{22}$ The inescapable implication of the Wolf case is that the federal exclusionary rule of the Weeks case, as a rule of evidence, serves only to deter federal officers from violating the "searches and seizures" prohibition of the fourth amendment. The protection which a federal court defendant receives is only incidental to this policy of deterrence. See note 26 infra. Cf. the language of Justice Frankfurter in the Wolf case: "Granting that in practice the exclusion of evidence may be an effective way of deterring unreasonable searches, it is not for this Court to condemn as falling below the minimal standards assured by the Due Process Clause a State's reliance upon other methods which, if consistently enforced, would be equally effective." 338 U.S. at 31 .

${ }^{23} 342$ U.S. at 121 . This recognition arises by negative implication only, since the Court declares that, even assuming the existence of an "important countervailing federal interest," injunctive relief will not always be granted. Citing Maryland v. Soper, 270 U.S. $9,36,44$ (1926).

${ }^{24}$ Any distinction between the general supervisory powers and the equity powers of the federal courts is likely to be misleading. The latter is, in effect, the principal method of exercising the former. Courts cannot direct the activities of government agents by administrative orders; at most, they can exercise an equitable power of injunction, or perhaps, as in the Weeks decision, formulate a rule of evidence with a view to controlling the conduct of law enforcement officers. 
authority which seeks to take advantage of that violation. This restraint could not encourage compliance with the federal rules; instead, its only effect would be to extend to the state defendant a protection to which, under the $W$ olf case, he has no federal right..$^{25}$

In light of this analysis, it appears that the crucial question presented by the Rea case is whether the issuance of the injunction will sufficiently deter illegal seizures by federal agents to justify the interference with state criminal proceedings. ${ }^{26}$ This deterrence factor is naturally commensurate with the extent to which federal agents advert to the admissibility of evidence which they are about to seize illegally. Since it is well recognized that illegally obtained evidence is in admissible in federal proceedings, ${ }^{27}$ federal officers are probably accustomed to think in terms of inadmissibility whenever evidence is illegally seized. Consequently it might be argued that to add the factor of inadmissibility in state proceedings is to pass the point of diminishing returns, particularly in those cases where it is most likely that the. federal officers are unaware of the state offense involved.

On the other hand, however, it can be argued that, since federal and state officers work in close co-operation in certain areas of law enforce-

\footnotetext{
${ }^{35}$ See note 22 supra.

${ }^{20}$ The element of deterrence, of course, was not present in the Wolf case, which involved the illegal seizure of evidence by state officers for use in state criminal proceedings. The theory that deterrence is the only underlying rationale of the Weeks rule is buttressed by the fact that evidence obtained by state officers by unreasonable search and seizure may be received in the federal courts. Lustig v. United States, $33^{8}$ U.S. 74 (1949); Byars v. United States 273 U.S. 28 (1927). In these cases the Court held that the tests for the admissibility of evidence in the federal courts was whether or not a federal officer was present at the time of the illegal search and seizure.

Prior to the Rea case, evidence unlawfully obtained by federal officers had, on occasion, been introduced in state prosecution when not in contravention of state law. In Commonwealth v. Colpo, $98 \mathrm{~Pa}$. Super. 460 (1930), the state court flatly rejected defendant's contention that the Weeks rule should exclude the evidence illegally seized by a federal agent. The United States Supreme Court denied certiorari. 282 U.S. 863 (1930). See also State v. Gardner, 77 Mont. 8, 249 Pac. 574 (1926); Terrano v. State, 59 Nev. 247,9 I P. 2d 67 (1939).

This policy of deterrence, it seems, can only be fully effectuated if the courts also evince a willingness to compel the exclusion of illegally obtained evidence in administrative proceedings. Generally, the technical rules of evidence are not binding upon administrative agencies. FTC v. Cement Institute, 333 U.S. 683, 705-06 (1948). However, the exclusionary rule of the Weeks case would seem to be applicable. Cf. Interstate Commerce Commission v. Louisville \& Nashville R.R. Co., 227 U.S. 88, 93 (1913); Bridges v. Wixon, 326 U.S. 135, 150-157 (1945).

${ }^{27}$ See note 19 supra.
} 
ment, ${ }^{28}$ inadmissibility of certain evidence in the state courts might substantially deter its seizure by federal agents. But, in order that this deterrent effect may be more fully realized, the Court must be prepared to enjoin state officials as well from introducing or testifying as to evidence illegally obtained by federal agents ${ }^{29}$ otherwise the injunction might operate primarily to encourage federal officials to surrender inadmissible evidence to the state agents as quickly as possible. ${ }^{30}$ Perhaps the Court would balk at such a "direct" interference with local law, but it should be remembered that the practical interference involved is no greater than if the injunction were issued against the federal agent. Finally, in support of the injunction, it might be observed that the reasons for excluding evidence illegally obtained by federal officers are more compelling than in the case of state officers, since the former are less responsive to redress under local law for their illegal action. ${ }^{\mathbf{3 1}}$

The above considerations are obviously not susceptible of any precise appraisal. For this very reason, however, it would have been desirable for the Court in the Rea case not to have asserted its supervision of federal officers as the primary source of its injunctive power, but rather to have considered this supervisory duty merely as a factor affecting the propriety of injunctive relief. If the Court had adopted this approach, the desirability of the result finally reached may still have remained debatable, but the opinion would, nevertheless, have stood as an authoritative evaluation of the state and federal interests involved and as a helpful precedent in the future adjustment of those interests.

\footnotetext{
${ }^{28}$ In addition to the field of narcotics regulation, federal and state officials frequently co-operate in the supervision of interstate gambling. Cf., Comment, The Fifth Amendment and the Federal Gambling Tax, 5 DukE B.J. 86, 87, n. 8 (1956). See also the Federal Firearms Act, 52 STAT. 1252 (1938), 15 U.S.C. § 901 (1952).

${ }^{20}$ Some support for this control over evidence illegally obtained by federal officers might be found in a federal statute adverted to in the majority opinion in the Rea case: "All property taken or detained under any revenue law of the United States shall not be repleviable, bnt shall be deemed to be in the custody of the law and subject only to the orders and decrees of the courts of the United States having jurisdiction thereof." 62 STAT." 974 (1948), 28 U.S.C. $\S_{2463}$ (1952). The limited relevance of this statute, however, minimizes considerably its effectiveness. In addition, it has no application to the testimony of a federal or state agent given on the basis of illegally obtained evidence.

${ }^{30}$ The dissenting opinion in the Rea decision foresees such a "race between a state prosecution and a federal injunction proceeding." 76 Sup. Ct. at 296.

${ }^{31}$ See Wolf v. Colorado, 338 U.S. 25, 30 n. I (1949).
} 